\title{
SZABÓ SZABOLCS (SZERK.): KÖZÉP-MAGYARORSZÁGI MOZAIK
}

\author{
(Társadalom- és Gazdaságföldrajzi Tanulmányok 3. Az ELTE Tár- \\ sadalom-és Gazdaságföldrajzi Tanszékének kiadványsorozata \\ Trefort Kiadó, Budapest, 2008, 239 o.)
}

\section{KONDOR ATTILA CSABA}

A Közép-magyarországi régió sajátos problémáiról, a „Budapest és vidéke” viszonyrendszerről szóló, az ELTE TTK Társadalom- és Gazdaságföldrajzi Tanszéke által megjelentetett tanulmánykötet a tanszék egykori és mai munkatársainak írásait tartalmazza. A könyvbe jórészt olyan munkák kerültek, amelyek korábban már másutt megjelentek, de a közös tematika (Budapest és szükebb környéke) egy gondolati láncra füzi fel őket. A kiadványban szereplő kilenc tanulmány közül az első hat írás elsősorban a régióra, $\mathrm{s}$ azon belül Budapestre vonatkozó társadalmi-gazdasági helyzetértékeléshez ad támpontokat, a következő rész - a tanszék újabb kori hagyományaihoz méltóan - három színvonalas tanulmányt tartalmaz a terület- és településfejlesztés témaköréböl. A könyv végén képekkel illusztrált megemlékezést találunk a nemrég elhunyt tanszékvezetőröl, Perczel Györgyröl, valamint tanszéki krónikát is olvashatunk.

A kötetet Mendöl Tibornak egy 1947-ben megjelent, Budapeströl szóló írása vezeti be, amely a Bulla Bélával közösen írt „A Kárpát-medence földrajza” c. könyv utolsó fejezetét alkotta. A szerkesztő által lábjegyzetelt munkát valóban érdemes ủjra elolvasni, mert igazán plasztikus képet ad a fỏváros szerkezetének kialakulásáról, illetve a második világháború előtti város múködéséről. A kỏvetkező tanulmány szintén egy régebbi munkának, Antal Zoltán és Bartke István 1998-ban született, a központi régióról szóló írásának újraközlése, ami a rendszerváltozás utáni Budapest életét, a nyugati világba történő reintegrációjának folyamatát, valamint a folyó és tervezett, a fővárosi agglomeráció mủködését serkentő fejlesztéseket, beruházásokat elemzi. A több mint tíz évvel ezelött született tanulmány és a szerkesztỏ lábjegyzetekben közölt aktuális kiegészítései alapján rádöbbenhetünk arra, hogy az agglomeráció életének elmúlt tíz évét sok tekintetben helyben járás, sőt bizonyos területeken visszafejlődés jellemezte. Az 1990-es évek végén egy mozgásban levő, magát Közép-Európa vezető városaként vizionáló és pozícionáló Budapest napjainkra tágabb régiónk igencsak középszerü, a tíz évvel ezelötti állapothoz képest kevéssé vonzó fővárossa lett. Az időutazás lezárásaként a Szerkesztő, Szabó Szabolcs tollából olvashatunk a Közép-magyarországi régió elmúlt 10 évének fontosabb társadalmi-gazdasági térfolyamatairól. Az összefoglaló, tudományos-ismeretterjesztő 
Tér és Társadalom 23. évf. 2009/3. 211-216. p.

jellegü írás a lényegi pontokon ragadja meg napjaink Budapestjének legfontosabb városföldrajzi folyamatait.

A következő tanulmányban Berényi B. Eszter Budapest belvárosának társadalmi megítéléséről ír, ami több kérdôives kutatás eredményeit foglalja össze. A Szerző érdekes és alapos elemzése a belső kerületekben elhelyezkedő mintaterületek népességének a lakóhelyhez kapcsolódó elégedettségét, eltérỏ lakóhelyi preferenciáit és költözési szándékait boncolgatja, amelyeket nem szabadna figyelmen kívül hagyni a belső területek fejlesztésekor.

Igazi kuriózumnak számít Szabó Sándor tanulmánya az egykori Csepel Mủvek iparterületének átalakulásáról. Érzödik, hogy a Szerző alaposan elmélyült a gyáróriás történetében, és a jelenlegi állapotokat is kiválóan ismeri. A tanulmány rávilágít arra, hogy a barnamezös területek megújításának egyik legfőbb akadályát a rendezetlen tulajdonjogi helyzet jelenti, amelyben Csepelen történt már némi előrelépés. Külön érdem, hogy a Szerző megpróbálja felvázolni az iparterület jövőképét, és az ehhez szükséges fejlesztési lehetőségeket, ha vázlatosan is, de megemlíti.

A következỏ oldalakon egy angol nyelvủ tanulmányt olvashatunk a nagyvárosi metabolizmusról Pomázi István és Szabó Elemér tollából. A biológiából kölcsönvett fogalom segítségével a Szerzők Budapest ökológiai lábnyomát mutatják be modern szemlélettel, környezetstatisztikai módszerekkel. Az elmúlt fél évszázad során jelentősen változott a föváros ,,anyagigénye”, ennek következtében átalakult a város által termelt szennyezőanyagok összetétele és mennyisége is. A munka adatokkal támasztja alá például, hogy a város vízigénye - ezáltal a kibocsátott szennyvíz mennyisége - csökkent a szocialista ipar összeomlása következtében, ugyanakkor a termelődő mủanyagok, illetve a közlekedési eredetủ légszennyező anyagok mennyisége mára számottevően megnött. A budapesti anyagáramlásoknak a Szerzők által felvázolt input illetve output oldalán 1990 után bekövetkezett jelentős csökkenése azonban a valóságban vélhetően azért nem okozott érezhető környezetminőségjavulást, mert a szuburbanizáció hatására a város ökológiai lábnyoma jelentősen kiterjedt. A felhasznált javak és a keletkező hulladék tekintetében ugyanis csalóka lehet kizárólag a főváros közigazgatási területét vizsgálni, számos, az agglomerációból származó kedvezőtlen ökológiai folyamat még a belvárosban is kitapintható.

Mint a bevezetỏben említettük, a könyv második része a Közép-magyarországi régióval kapcsolatos terület- és településfejlesztési írásokat tartalmaz. Elsőként Gordos Tamás tanulmányát olvashatjuk a régió területfejlesztési eszközeiről. A gyakorlati tudás segítségével megírt munka - ami a Szerző doktori disszertációjának is része - nagyon alapos, minden lényeges kérdésre kiterjedően tárja fel az elmúlt tíz évben a régió számára nyitva álló fejlesztési lehetőségeket, és kitér az aktuális forráslehetőségekre is. A puszta felsorolásnál jóval többet nyújt a Szerző azzal, hogy bátran elemez, értékel, s következtetései feltárják a magyar regionális területfejlesztési (forrás)rendszer alapvető hiányosságait és hibáit (pl. nem megfelelő hatékonyságú központi beruházási forrásrendszer, a decentralizáció és a versenyképesség-erősitő szándék hiánya stb.). Joggal remélhetjük, hogy napjaink gazdasági válsága következtében a támo- 
Tér és Társadalom 23. évf. 2009/3. 211-216. p.

gatási rendszer a presztízs-, illetve látványberuházások helyett egyre inkább a gazdaságfejlesztést fogja preferálni, ami végre valódi értelmet ad majd a területfejlesztésnek.

A következő tanulmányban Loydl Tamás a település és a terület fogalmát járja körbe tudományos igényességgel, majd megállapítja, hogy hazánkban a településfejlesztés szabályozásának elhanyagolásával a tér „kettészakadt”. A Szerző térelméleti fejtegetései rendkívül érdekesek, a levont gyakorlati következtetései mellbevágóak. A településfejlesztés szabályozásának elhanyagolása ugyanis a területi folyamatokra komoly hatással van. Ezzel a ténnyel a gyakorló szakember nap mint nap szembesül: mégiscsak abszurd például, hogy a településfejlesztés alapvetö fogalmait és eszközeit évről évre különféle, változó terjedelmü, kétes legitimitású „kézikönyvek” tartalmazzák... Reméljük, hogy a Szerző alaposan kiérlelt és megokolt mondanivalója a jogalkotóknál valamikor meghallgatásra talál.

Az utolsó tanulmányban Szabó Szabolcs a budapesti agglomeráció közlekedési eredetủ konfliktusait elemzi, különösen az M0 történetének példáján. A nagy elméleti igénnyel megírt munka definiálja az agglomeráció közlekedési szereplöinek csoportjait, és ezek alapján a fővárosi közlekedésfejlesztést, mint az egyes érdekelt csoportok konfliktusainak igazi terepét szemlélteti. A következtetések általában helytállóak, bár néhol talán túlzóak, ilyen pl. a civil szervezetek kompromisszumkészségének teljes hiányára utaló kitétel. A tapasztalatok szerint a civilek akkor válnak igazán dacossá, amikor a megfeleló szintü participáció hiányát érzékelik. Mindenesetre a tanulmány következtetései megerósítik azt a tételt, hogy eredményes és a lehetố legkevesebb konfliktussal járó közlekedésfejlesztést csak tényleges, kollaboratív tervezés eredményezhet. Persze, ehhez új politikai szemléletre lenne szükség.

A tanulmányok átfogó ismertetése után röviden említést kell tennünk azokról a hibákról is, amelyek a könyv élvezeti értékét erősen rontják. Napjainkat „tanulmánykötet-boom" jellemzi, sokszor a megjelenő munkák valódi értéke erősen megkérdőjelezhető. Tartalmi értelemben ez a kiadvány sem mentes olyan ,gyermekbetegségektöl", amelyek sok esetben felületességröl árulkodnak. Tárgyi tévedések, illetve a fogalmak nem következetes használata elsősorban a fiatalabb szerzőknél fordulnak elő. Találunk olyan tanulmányt is, amelynek néhány sora kísértetiesen hasonlít egy, már korábban megjelent irás soraira, de a hivatkozást hiába keressük. A kötet szerkesztési problémáktól sem mentes: rengeteg az elütés, néhol mondatszerkesztési hibák is elöfordulnak, sőt félbehagyott bekezdéssel (!) is találkozunk. A tartalmi mondanivalóra is kihat az, hogy sok ábraaláíás felcserélödött, az olvasónak kell kibogarásznia a szövegböl, hogy mit is takar az adott ábra. Az ábrák minősége is több esetben hagy kívánnivalót maga után. Mindezek arra engednek következtetni, hogy a betördelt szöveg korrektúrája nem vagy csak felületesen történt meg. Nem érdemes sajnálni egy fél napot erre, ezzel ugyanis megkímélhetjük magunkat néhány emlékezetesen kínos hibától.

Mindezek mellett elmondható, hogy a már első ránézésre is érdekesnek tünő kiadvány igényesen összeválogatott „tudományos mozaik”, amelynek elolvasása közelebb visz minket a „Budapest probléma” megértéséhez. A tanulmányok nyelvi, tartalmi és kronológiai mozaikossága teszi igazán érdekfeszítővé a könyvet. A változatos 
mondanivaló és az egyes írások optimális terjedelme következtében ezt a kötetet érdemes ,egy az egyben”, az elejétöl a végéig elolvasni, ami azért kevés tanulmánykötetről mondható el. Fontos lenne, hogy a könyv írásait - kisebb-nagyobb hibái ellenére - az egyetemi oktatás segédanyagaiként is felhasználnák, mert azok hozzájárulhatnak a jövő településfejlesztési szakemberei látókörének szélesítéséhez. 